This is the post print version of the article, which has been published in Sociological review. 2017, 65

(2),285-301 . http://dx.doi.org/10.1177/0038026116675554.

This document has been downloaded from TamPubutafi The Institutional Repository of University of Tampere

\title{
Re-visiting NIMBY: From Conflicting Interests to Conflicting Valuations
}

Veikko Eranti (corresponding author)

University of Tampere

School of Social Sciences and Humanities

University of Helsinki

Department of Social Research

Veikko.eranti@gmail.com

Please find the published version from

http://journals.sagepub.com/doi/abs/10.1177/0038026116675554.

\begin{abstract}
:
This paper presents a new way of understanding local land-use conflicts, also called NIMBY, developing from justification theory and literature from the sociology of engagements. The article builds on the multiple systems of valuation used by people to perceive local land-use cases as conflicts, following the pragmatic sociology of Boltanski and Thévenot $(1999,2006)$. The conflicts are shown to be not only about conflicting interests of the residents, but also about broader conflicting systems of valuation. Empirically, land-use cases in Helsinki, Finland are analysed to show the variety of argumentation used by residents opposing land-use. Over 500 dispute letters are analysed, vast majority of which base their argumentation on common good. About $40 \%$ also use argumentation based on individual interest. Argumentation based on close familiar affinities is rare but existing, which might be because of the type of data used in the article. The framework used allows for the non-moralising use of the concept NIMBY when describing the conflicts.
\end{abstract}

\section{Keywords:}

NIMBY, participation, justification, urban conflict, urban planning, valuation

\section{Acknowledgements:}

The author wishes to thank Eeva Luhtakallio, Gemma Edwards, Tuukka Ylä-Anttila, Tomi Lehtimäki, Georg Boldt, Senja Laakso, the Helsinki Research Group on Political Sociology, and two anonymous reviewers for their extremely helpful comments on this article. This work was made possible by a working grant from the Kone Foundation, for which I am grateful. 


\section{Introduction}

Land use is always contested. From 19th century British villagers protesting against mental asylums (Bucknill, 1858; Philo, 1987), to US environmental activists protesting against toxic soil in residential areas (Bullard, 1990), to 21st century Greeks protesting against landfill sites (Botetzagias and Karamichas, 2009): across different historical and physical settings, people sometimes rise up against developments in their immediate surroundings. These conflicts happen pronouncedly in cities - with a great number of people comes a greater number of interests and opinions.

How should these protesting residents, and the conflicts (often called NIMBY, or 'Not In my Back Yard') be understood? Earliest research on the issue of conflict led researchers to describe the motives of residents primarily from the perspective of individualist self-interests (Wexler, 1996, Freudenberg and Pastor 1992). More recent studies focus on the interplay of local environment, broader cultural factors, citizenship, and the individual and her interests - and call into question, whether the stereotypical NIMBY is based on individual interests exists at all (Bell et al, 2013; Burningham et al, 2006; Hager and Haddad, 2015; Gibson, 2005; Trom, 1999; Lolive, 1997; Thévenot, Moody \& Lafaye, 2000; Neveu, 2002).

Recently, NIMBY conflicts have been understood as an integral part of democratic land-use processes (Mannarini and Roccato, 2011), and the residents acting against planning changes as being motivated by something else than purely private interests (eg. Lolive, 1997; Kempton et al, 2005; Bell et al, 2005; 2013). Often by more general-level worries about the effects of the particular land use, or by a familiar attachment to the said places. Following Wolsink (2006:90), it can be said that local land-use conflicts are always about fairness (or justice): whose voice is heard, whose interests are taken into account, and how arguments are valued. But what is 'fairness'? In these land-use conflicts, actors use it in so many incommensurable ways that the conflicts should be 
understood as being about what fairness and justice are, and how they are valued in each specific case.

In this paper, I present a framework for understanding this question of justice and fairness in local land-use conflicts. The framework is based on the pragmatic sociology of Boltanski \& Thévenot (1999; 2006; see also Thévenot, 2014, 2015). When opposing local land-use projects, in addition to the actual arguments residents use, they also try to qualify the dispute and the particular local environment (Trom, 1999; Lolive, 1997; Thévenot, Moody \& Lafaye, 2000). This is done in order to settle, which way of valuing the local environment should be seen as the situationally correct one - which mode of valuation should be used (Centemeri, 2014). The primarily self-interested NIMBY-opposition of the earliest research is but one of the possible modes of valuation, the other two being the familiar attachments to places and common-good based justifications. I argue that a framework like this is needed to understand what these conflicts are about both from the perspective of the residents participating in them, and in a way that is relatable to broader sociological theory on critique.

To empirically show the differences between the systems of valuation, and the difference it makes, I analyse the argumentation residents of Helsinki, Finland use, when they are opposing land-use projects in their neighbourhoods. I analyse 565 dispute letters, concerning 42 land-use cases sent by the residents to the city planning official. I focus on two specific urban development projects, and the critiques presented against them. From the point of view of the resident activists, in Haaga, new high-rises are destroying an idyllic, and historically lush and green, neighbourhood; and in Rastila, a locally beloved forest is being zoned for luxury condos. Or are these cases, as the city administration argues, about building more housing for families in a growing city? This article analyses, how local residents evaluate these situations, and how they present the conflict to the city planners. 
By using a framework based on the modes of valuations, it is possible to empirically look at differences and similarities between land-use conflicts, using non-normative concepts. Thus questions about the general responses towards land-use conflicts (do the 'NIMBYs' who argue primarily based on their own interest, exist?) can be answered, and comparisons between cases made in an analytical fashion.

The macro-level empirical perspective is highlighted in this article by focusing on written dispute letters sent by residents to city planners. The way these dispute letters conform to official participation channels also helps to highlight the fact that movements in NIMBY conflicts often work both against and in parallel with the established bureaucratic democratic processes. The aim of NIMBY activists and actors can be seen as not only protesting against planning processes, but in different ways complementing and challenging it, thus ensuring the legitimacy and acceptability of land-use decisions on a larger scale (Gibson, 2005; Rosanvallon, 2008). This helps to highlight that the most 'traditional' NIMBY argumentation, based purely on the self-interest of the actor, should also be seen as primarily political, not parochial, act.

\section{NIMBY: a label for conflicts}

The concept NIMBY has a troubled past that traces back to United States of the 1970s. New environmental justice movements were born to fight for the rights of people living in houses built on polluted lands. For the activists, the central meaning of these movements was empowerment, righting the wrongs the system had done to them: they were at least partly class-based, from poor white neighbourhoods. (Bullard, 1990; Burningham et al, 2006; Engelhaupt, 2008.) Sherman (2015) traces the actual term to pejorative use by industry executives working against these local protests.

Within academic literature, NIMBY was introduced by Dear and Taylor's Not On Our Street (1982). In his influential paper, Dear (1992:228) defined NIMBY as 'protectionist attitudes of and 
oppositional tactics adopted by community groups facing an unwelcome development in their neighbourhood... residents usually concede that these "noxious" facilities are necessary, but not near their homes.'

Earliest academic discussion was chiefly concerned with giving practical tips to planners on how to conquer the obstacles to building and development (Freudenberg and Pastor, 1992; Inhaber, 1992; Wexler, 1996). These early studies saw NIMBY from technocratic planners point-of-view (see Mannarini \& Roccatto 2008): primarily as a constraint for effective planning. They often describe NIMBY in medical terms, as a 'syndrome' to be cured (Szasz, 1994). In the 1990s, NIMBY was understood as a tool of racial and class separation that better-off areas used to pre-empt problems in their area - sometimes called environmental racism (Hamilton, 1995). More recently, NIMBY has been seen as a hindrance to sustainable development and green infrastructure. The studies on citing wind turbines, nuclear power plants and waste management facilities still find that these projects face considerable opposition, but not all of it is seen as inherently negative as in earlier research (Botetzagias and Karamichas 2009; Shumaway and Jackson, 2008; Bell et al, 2013; Kempton et al, 2005).

NIMBY and local opposition have also been related to broader ideas of democratic participation (Lolive, 1997; Trom, 1999; Neveu, 2002; Gibson, 2005; Roccato et al, 2008; Mannarini and Roccato, 2011; Richard-Ferroudji 2011; Hager and Haddad, 2015). This participation happens through voicing of concerns or critiques towards the land-uses -often argued on a more general level than purely out of the self-interest of actors - and could be interpreted two ways. Either as local and particular critique against new developments (Wolsink, 2006) or as expression of general will: if some developments always meet opposition, maybe they really are against what people everywhere want (Gibson, 2005)? The local opponents are seen as presenting legitimate critiques 
against land-use cases: rising from the local level, against central planners and big business interests.

The literature has been rather consensual in recognizing conflicts seen as NIMBY (see eg. Hager and Haddad, 2015). The same cannot be said of the conceptual positions taken by writers, or of how moralities, or questions of fairness and justice, are addressed in these conflicts. According to Feldtman and Turner (2010), research on NIMBY has been highly normative, even moralising.

Kempton et al (2005:124-5) offer three reasons for not using the term NIMBY: 1) It has pejorative connotations 2) It may not accurately describe the phenomenon 3) it is a label that leaves the cause of opposition unexplained. NIMBY is seen to connote a selfish view of the residents, acting only out of their own interest (Freudenberg \& Pastor, 1992; Burningham et al, 2006; Burningham, 2000; Gibson, 2005; Wolsink, 2006). In reality, the residents are using much more sophisticated argumentation (Lolive, 1997; Trom, 1999; Neveu, 2002; Richard-Ferroudji 2011).

The term NIMBY, thus, works best as a descriptive term: it is widely used (in virtually all literature referenced here) and does a good job at describing what the conflicts are about: residents opposing changes in their local surroundings. NIMBY as a term evokes the clash between what the local actors want, and what the planners or developers want, and an emphasis on the actors. 'Not in $m y$ backyard' has a connotation of active participation, whereas the main alternative, locally unwanted land-use, can be seen to connotate attitudes instead of action.

The critiques of the usage of term NIMBY posit that even when used as a descriptive term, it still contains implicit notions about role of private interest of the residents - that it is a normative term at heart. In this paper, instead of relying on these implicit notions, I take them explicitly as the research question. Following Hubbard (2006), this paper does not aim at classifying 'some nimby campaigns more "valid" than others'. To avoid the problems of using the term NIMBY with its 
moralising undertones, I argue that the most fruitful sociological approach is to understand NIMBY conflicts as being more about conflicting modes of valuation and how situations are evaluated by the actors (Lamont, 2012; Centemeri, 2014), as they are about residents' conflicting interests in local issues.

These conflicts, and particularly individual people acting against land-use decisions in their own surroundings, are not monoliths: they do not all act based on either a single system of valuation, or a shared sets of common principles. Complex conflicts involving multiple stakeholders include complex sets of moral principles. By taking into account the multiple systems of valuation used by people, local land-use conflicts can be understood in a more analytical fashion.

As many writers (Bell et al, 2005; 2013; Devine-Wright, 2009; Trom, 1999; Lolive, 1997: Neveu, 2002; Moody \& Thévenot, 2000) have noted, in local land-use conflicts, the actors refer to their own private interests sometimes - but more often not. Rather, they argue with both more generalized and principled, as well as more emotionally invested, arguments. These arguments are, naturally, often quite aligned with their own interest.

The three level model of NIMBY, based on pragmatic sociology (Thévenot, 2015; Boltanski \& Thévenot, 2006) and presented in the next section, accommodates these different types of argumentation. They range from private interests and deep familiar engagements with local surroundings, to a general level principle-based argumentation. Thus, NIMBY conflicts can be analysed without making assumptions of the argumentation, or motives, of the residents.

Gibson (2005) sees NIMBY as voicing of an opposition against a planned development rising from conflicting interests of the people and the planner. In some political cultures (Moody and Thévenot, 2000; Thévenot \& Lamont, 2000 compare France and the US), this kind of opposition is not only legitimate, but rather a central type of political argumentation. NIMBY protests can be seen as 
instances of suspicion against central planning (Rosanvallon, 2008), even if they are only based on the self-interest of actors. And if this acceptability is more a feature of political culture than a feature of land-use conflict in itself (Luhtakallio, 2012), it means that even if local residents are only acting on their own interest, they should be analysed as citizens participating in democratic processes, not as second-class citizens (Neveu, 2002).

\section{NIMBY as a conflict of modes of valuations}

The pragmatic sociology of Boltanski and Thévenot, (2006) posits that every individual has a critical capacity (Boltanski \& Thévenot, 1999) - a potential to solve conflicts and criticize situations they find unjust. A land-use decision by the city planner that local residents perceive as threating the local area is a good example of such a situation: the residents are able to produce a broad range of different critiques against the proposed land-use. The original model, presented in On Justification (Boltanski and Thévenot, 2006) included six definitions of common good that can be used as sources for this critique ${ }^{\mathrm{i}}$.

To shift from values to modes of valuation (see eg. Centemeri, 2014; Thévenot, 2015), I present a framework based on the sociology of engagements (Thévenot, 2007, 2014, 2015) and the advances in the theory made since (Luhtakallio, 2012; Ylä-Anttila and Luhtakallio, 2016). Thévenot (2007) proposed the idea of three different types of engagement with the world; one based on public justifications, one on familiar close affinities, and one on the individual interests. When these three engagements operate on the level of community, that is, on the level of political argumentation, Thévenot (2015) calls them grammars of communality, (later shortened to grammars). I propose to understand NIMBY conflicts via three different systems of valuation, based on the three grammars: Individual Interests, Public Justifications and Familiar Affinities. 
In this article, the grammars (Thévenot 2015) are operationalized within the (at least semi-) public realm of argumentation. The French pragmatic approach has been used in research on local land-use conflicts (Richard-Ferroudji, 2011; Thévenot, Moody \& Lafaye, 2000; Centemeri, 2014; Gladarev \& Lonkila, 2013; Blok \& Meilvang, 2014). These writers have focused on either developing the theoretical model (Centemeri, 2014; Thévenot \& Moody, 2000), or on close inspection of the engagements in single conflict (Gladarev \& Lonkila, 2013; Blok \& Meilvang, 2014). In this paper, I take a more macro empirical perspective - looking at a broad range of land-use conflicts in Helsinki. In this framework, the practical grammars of valuation (Centemeri, 2014) are seen as cultural resources used by actors within society (Swidler, 1986; Luhtakallio, 2012;). I present the three grammars, understood as modes of valuation used in argumentation (For a summary, see Table 1 on page 12).

The Individual Interests system of valuation is based on the self-interest of actors, or residents in NIMBY cases. Rosanvallon (2008: 25-26) identifies a type of fundamental suspicion and opposition against elected or otherwise ruling political organs, being based on a liberal disbelief about whether general will exists at all. This suspicion is central for some NIMBY analyses (Gibson, 2005): idea is to protect the individual and her interests against the central planner or decision maker. The fundamental of scale of valuation is that of the individual interests - and the stress is on the legitimacy of these interests (Moody and Thévenot, 2000; Thévenot, Moody and Lafaye, 2000, Thévenot \& Lamont 2000).

Many earlier analyses of NIMBY conflicts were rooted in the idea of the private interests of liberal individuals (Freudenberg and Pastor, 1992, Gibson 2005). Common good is not only hard to define in some cases: it might be completely misleading as a concept. This conception of democracy argues that the greater good emerges through a system in which all actors act purely out of self- 
interest. On rhetorical level, the actors might make demands, broker deals and issue ultimatums, not argue about principles on general level. (Thévenot 2014, 2015; Moody and Thévenot, 2000).

For Thévenot $(2014 ; 2015)$ the individual is the crucial actor in the grammar of individuals. There is, however, no fundamental reason, why the analysis could not be broadened to include also small groups of individuals. This is only possible, if this mode of valuation is based on the usage of interests - non-justified political claims - instead of the way of engaging the world through plans or the continuation of normal action, as has been previously done (Thévenot, 2007; Centemeri, 2014). The context of urban land-use conflict seems to be particularly well suited for this kind of expansion of the role of these private interests within the the sociology of engagements - thus far underdeveloped - because of the role private interest plays in the 'classical' idea of the NIMBY (Freudenberg \& Pastor, 1992; Burningham, 2000)

On the most general level, the level of Public Justification, all argumentation and valuation is based on the common good - which can be defined in many ways. These definitions are acceptable and recognizable for all actors in a given society. Even though we might disagree with the use of a particular common good in a particular situation, we recognize that it might be legitimate in a different situation. (Boltanski and Thévenot, 2006). This is the style of argumentation which is mostly easily understood as 'political', or value-based and principled, and what many writers refer to, when talking about 'justified' or 'prudent' NIMBY (Freudenberg and Pastor, 1992) - or 'qualified opposition' (Bell et al, 2013 - see also Richard-Ferroudji, 2011).

For the definitions of common good (orders of worth in Boltanski \& Thévenot 2006; Lafaye and Thévenot, 1993), in this article I focus on nature (green worth), monetary good (market worth), and tradition (domestic worth) as basis of valuation. Ylä-Anttila and Luhtakallio have developed the idea of these valuations used in the public into an analytical tool, they call Justification Analysis (2016, see also Luhtakallio, 2012). 
In comparison with the mode of valuation based on individual interests, the grammar of public justification is marked by a rise in the level of generality (Boltanski \& Thévenot, 2006), a move from the individual or the small group to the level of the whole community. Lolive (1997) presents this rise as a strategy used by residents to sidestep being labelled (or analysed) as NIMBYs.

The politics of NIMBY conflicts cannot be reduced to either individual interests, or abstract dealings of common good. Many NIMBY conflicts are all about the particular - particular place, particular land use, and particular people. Land use conflicts are filled with specific material arrangements with meanings attached to the most intimate surroundings of people.

In the valuation based on familiar affinities and ties to the material and immaterial surroundings, places and ideas, are most important. This mode of valuation is based on emotions and strong personal connections. These feelings are not easily generalized (Thévenot, 2015), but can be used politically because of their almost visceral importance to the individuals (Ylä-Anttila 2016). The relation of personal affinities and urban commonplaces, and urban protest movements is elaborated by Blok and Meilvang (2014): the abstract diagrams of urban planning can be made sites of protests and conflict by supplementing them with tokens and explorations of personal relations to these places. Devine-Wright (2009) has used the term 'place-protector' to denote a similar type of argumentation or participation.

Within this framework, all argumentation uses the local environment as a resource. This environment is not an objectively existing thing, but rather has to be constructed as such by the people living there, by using some sort of evaluative criteria (Lolive, 1997; Trom, 1999; Centemeri, 2014). When one argues for the conservation of a forest area, one constructs the forest as a meaningful, perhaps even unique place within the environment. At the same time, the planning official might just see an underdeveloped plot of land. 
To sum up, argumentation in local land-use conflicts can be said to have three different modes of valuation usable for critique: 1) valuation rising from individual interests (endangered forest-views and property values of a single resident); 2) a publicly justified general political position (required amount of green recreational space in residential areas), and 3) the importance of close familiar affinities to particular environment (the strong emotional importance of a specific small forest). These three modes are summed in table 1 below.

\begin{tabular}{|l|l|l|}
\hline Mode of valuation & Basis of Argumentation & Example from the Data \\
\hline Individual interests & $\begin{array}{l}\text { Arguments based on private } \\
\text { interest }\end{array}$ & $\begin{array}{l}\text { 'We cannot accept these new } \\
\text { buildings, as they would } \\
\text { negatively affect the value of } \\
\text { our assets.' }\end{array}$ \\
\hline Public Justification & $\begin{array}{l}\text { Arguments based on common } \\
\text { good }\end{array}$ & $\begin{array}{l}\text { 'Haaga has always been a lush } \\
\text { green area, and it should be } \\
\text { allowed to be that way. Each } \\
\text { part of the city has a right to } \\
\text { stay unique!' }\end{array}$ \\
\hline Familiar Affinities & $\begin{array}{l}\text { Arguments based on strong } \\
\text { emotional ties to places and } \\
\text { objects }\end{array}$ & $\begin{array}{l}\text { 'I was raised here, and my } \\
\text { daughters will be raised here. I } \\
\text { want to give them access to the } \\
\text { dear forest where I spent my } \\
\text { youth.' }\end{array}$ \\
\hline
\end{tabular}

Table 1: Three modes of valuation. 


\section{Land Use and planning in Helsinki}

The Finnish Land-Use and Building Act, which regulates planning and urban development, was renewed in 1999 to include ideas influenced by communicative planning and deliberative democracy (Saad-Sulonen 2014: 40-43, Haila 2002, Bäcklund 2007, Ministry of the Environment 2014, 151-156; Staffans 2012, Bäcklund \& Mäntysalo 2010). The act gives residents of a city the right to be heard when urban plans are amended and significant new developments are planned, and to challenge the legitimacy of these changes in court.

In Helsinki, the hearing process is organized both via specialized events and by giving residents a change to send dispute letters to the city planners. According to the law, these letters have to be 'taken into account' in the planning process. After drafting and comments, the Planning Authority creates an official plan proposal, which is then approved, rejected or amended by the City Planning Board of Helsinki (City of Helsinki, 2015). This implementation grants individual citizens, even without any formal organizational ties, a guaranteed way of receiving at least the formal attention of the city planning officials. Where the local planning officials in Finland used to see themselves as being in a position where they could define what is a good city, they now have to be part of a discussion about what is the common good (Bäcklund et al 2014, Bäcklund \& Mäntysalo 2010). The usage of deliberative instruments in itself does not necessarily lead to a more egalitarian participation, despite the nature of the participatory systems used. It can also work to hide power relations (Richard-Ferroudji, 2011).

While the Land-use and planning act itself might be influenced by the ideas of deliberative democracy, at the same time it also legitimizes any elements of liberal or aggregative democratic participation (Bäcklund \& Mäntysalo 2010). The law and the practices and implementations it encourages, are built on the ideas of common good and deliberation, but it also grants ample rights and ground for individual interests. It does that by recognizing them and their interests as 
legitimate. Richard-Ferroudji (2011) uses the sociology of engagements, and a similar framework to the one applied here, to present different participation methods that would be relatable to different modes of valuation. In the Helsinki participatory planning process, all arguments are presented, in a way, as equal: they are all presented as letters to the planning officials, expressing written argumentation (see Centemeri, 2014 for pragmatic approach to this kind of incommensurability).

This article uses the dispute letters sent to planning-authority by individual residents in land-use cases. These letters were mostly sent using email, with few letters each by a comment form on the City Planning Office website, mail, and postcards. Using these dispute letters as data gives us an interesting view of the local land-use conflicts. Since the process is something less than explicitly public in nature, participants do not face the fears of publicity, losing face or having a negative comment associated with them ${ }^{\mathrm{ii}}$. It is possible to directly asses the actual action and critical capacity performed by these resident (Boltanski \& Thévenot 1999), and, at the same time, rely on their belief that their argumentation is legitimate the context - were it not considered legitimate by the residents themselves, they most probably would not have used it. Legitimacy is thus defined by the residents: the argumentation they use is the one they, in practice, consider legitimate.

\section{Haaga and Rastila - two changing urban environments}

The analysis uses, firstly, a subset ${ }^{\mathrm{iii}}$ of all the dispute letters sent by residents to the city planning authority. They were processed by the city planning authority during 2012. The subset includes dispute letters from 42 different land-use changes, and 321 in total. Of these letters, $72 \%$ were against the proposed planning change (with 10\% ambivalent, and 18\% favourable).

I focus on a more detailed analysis of two specific land-use conflicts. In Haaga, the proposed changes were mostly incremental in nature. 700 new apartments were designed to be in the same price range as the existing apartments. The city planning authority received 107 dispute letters. The 
Rastila case was more radical in nature. The central idea was to replace a small forest area, currently used for recreation, with a new urban development for 15000 residents. The city planning authority received 137 dispute letters. Thus, the total number letters in data is 565 . These areas are middle-class, with Haaga in the more upper and Rastila in lower end of the spectrum.

These two conflicts were chosen, because they both contained a high number of dispute letters, but were different in nature: the first local and conservative in nature, the second more radical and widely contested.

\section{Valuations in land-use conflicts}

The comments in the dispute letters were categorized in three broad non-exclusive categories based on the system of valuation used: 1) those using individual interests as primary mode of valuation, 2) those in which a more abstract common good was presented as the main rationale for the opinion, and 3) those which based their valuation on the close familiar affinities and emotional ties between individuals and their surroundings. The central function of the dispute letters analysed here is to oppose specific changes in specific areas - the senders try to ensure that their specific mode of valuation and the things they consider worthy are taken in to account in the planning process. They do this, partly, by presenting the local environment in a way that supports their claims. The classification based on the close reading of the letters: Each letter was categorized based on the mode of valuation, which was used as the base of the argument. Letters using multiple modes of valuation were counted in each class.

Figure 1 presents the distributions of the used modes of valuation in the dispute letter. Over $40 \%$ used argumentation that was directly referenced the individual interests of the writer. In Haaga, these were often rather straight-forward economic arguments. For example, one commenter wrote: 
'the planned new building would affect the economic interests of the current residents significantly, in a negative way.'

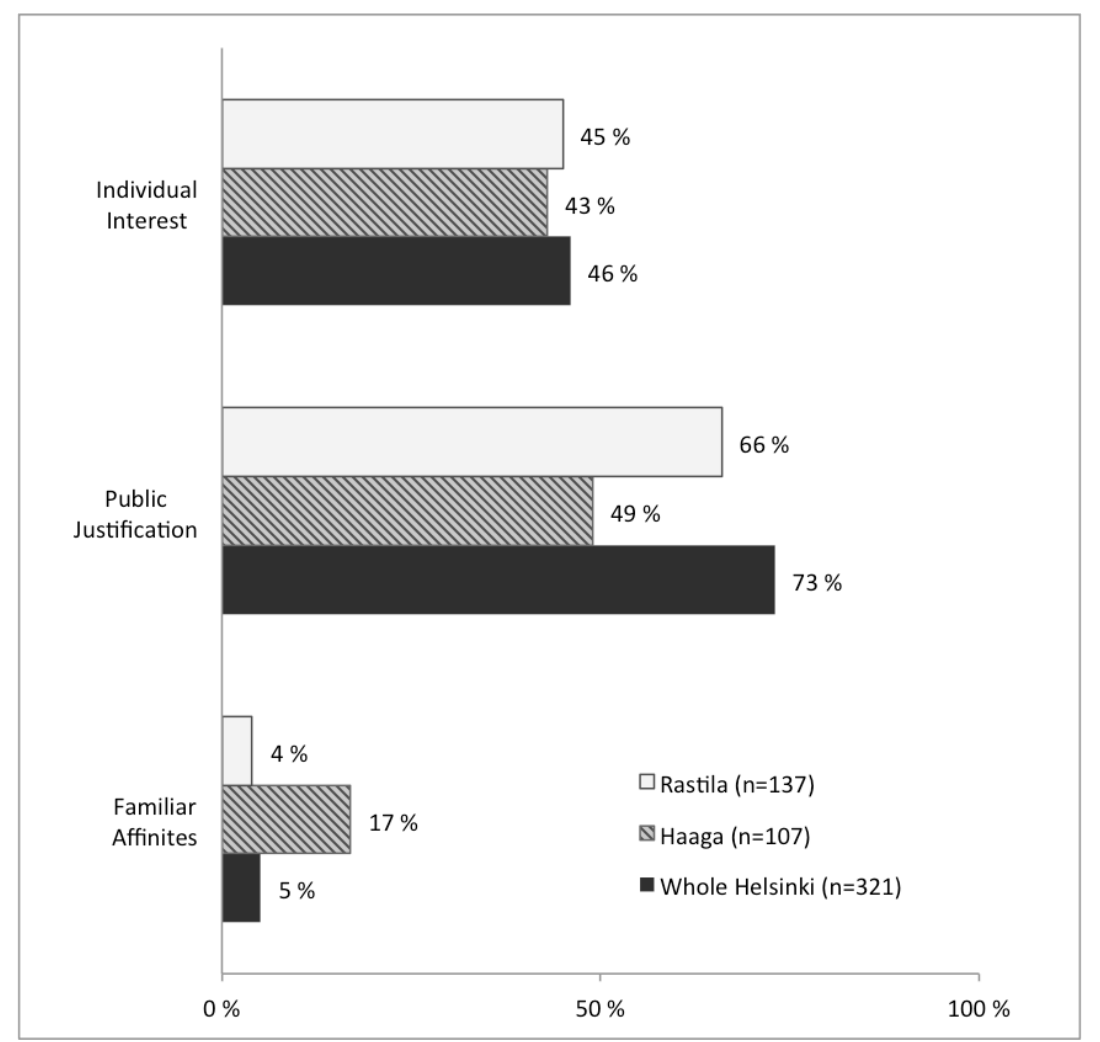

Figure 1: The distributions of the three modes of evaluation, with non-exclusive categories, per cent.

Another way of using the Individual Interests as the basis of argumentation is to open the conflict up for trading. In many situations, the interests of the people currently living in an area are different than the interests of potential future residents. Some current residents of Haaga threaten the city of Helsinki with moving away from the area, if the plans are executed: 'If all of [the proposed changes] really become reality, I shall pack my family and move to greener and more lush surroundings. When I have discussed this with my friends here at Haaga, they have all said the same.

One commenter from Rastila highlighted the choice made by when moving in the area: 'I ask that you would also value the opinion of the people like me, who have chosen to live in this area!' The fundamental value placed on individual opinion also manifests throughout the city as disputes that 
simply state their opinion without justifying it or explaining it in any way. On can assume these commenters think that voicing one's interest in the subject is an effective way of influencing the decision. The (legal) rights of the individuals figure prominently, such as in the concern that the city is using its powers over land-use in a way that is harmful to them, or their small community.

Interest-based valuations are not always presented from the point of view of a single individual. The residents often present themselves as spokespersons for 'greater community of the Area'. This community is always seen as a unanimous actor, and is constructed by the speaker to back her claim. In the next quote, a shift from 'I' to 'we' can be noted: 'Hey. I'd like to express my opinion on this matter. Haaga is already dense enough as it stands. Once the green areas are refurbished and a new park building is built to replace the old one, it's enough. (...) And we don't want more traffic on our streets.' Here, even though the community is evoked as a rhetorical strategy, the mode of valuation does not include higher common principles such as common goods - it relies on the construction of the local community as a right-bearing subject, similar to an individual. A similar shift happens In Rastila: comments based on individual interest often focus on how valuable the green area under threat was for the current residents, and how much they are benefiting from the area.

This community-based way of presenting the argument does not alter the underlying assumption about valuation: what residents see as valuable, should be seen as valuable by the planners as well. This is the core logic of the valuation based on individual interest. It is not based on principled arguments about common good, or about deep and meaningful bonds with nature, but on statements of preferences.

In both Rastila and Haaga, using public justification was most common (66\%, and 49\%, respectively, compared to $73 \%$ at city level). The argumentation in these letters is on a more 
abstract level. If comments based on individual interests are always grounded in the individual or small group, common good by definition calls for universal valuation.

One explanation for the dominance of arguments based on common good in Rastila was that the debate about the case did not remain between the city planners and the local people. It spilled over to newspapers, demonstrations and TV. A group of volunteer city planners created an unofficial alternative city plan for the area (Ourcity 2012). All in all, the residents of Rastila had organized themselves as a social movement, and the conflict could be seen as a local power conflict which one side tries to 'upscale', to win it on a more general level of discussion (Hogenstijn, van Middelkoop and Terlouw, 2008: 154).

Public justifications show differences between Haaga and Rastila. In Rastila, third of the residents argued for using ecological values in the assessment of the planning change: 'The Forest is a habitat for a diverse group of animals and plants, including foxes and birds. It should be preserved for future generations.' In the letters, the residents construct their environment as valuable chiefly because of its flora and fauna, not because its beauty or use-value.

In Haaga, the by far dominant justification was based on the traditional outlook and heritage of the area. Residents argued that the proposed changes would demolish the green and lush nature of the area: 'All the new buildings should adhere to the original design principles of the area: they should be small-scale and open, to preserve the park-like nature of the area. This lush park-like feeling is the unique aspect that creates the uniqueness and charm of Haaga.' The local environment was constructed as a heritage site, a place with history and a unique design. Even though both conflicts are about urban green areas, the justifications used in defending them were different.

Familiar attachments were rarely used in the dispute letters. It was used in $5 \%$ of the letters in the citywide sample, $4 \%$ in Rastila and $17 \%$ in Haaga. Its rarity in Rastila can be explained by the 
public nature of the conflict: in discussion where public justifications are assumed to be the norm, personal affinities can be easily pushed out of discussion (Thevenot, 2015). It might also be because of the nature of the data: personal engagements are not easily presented in a (semi-)formal complaint letter.

When these personal affinities are used as the basis of argumentation, it happens in the form of a story that establishes the deep personal connection the commenter has with the area, such as in the following example from Rastila:

I was born in this area and as a child I loved roaming in these forests. I lived elsewhere, in other cities and also abroad, but when it came time to start a family, I knew I wanted to do it here. It is really important to me that my children can play in the same forest in which I played as a kid. Yesterday, my daughter asked me, 'mommy, can you promise me that they won't destroy our forest?' Oh, how I wish I would have been able to promise her that.

While the writer is, naturally, arguing for her own good, inasmuch they all are, the difference between colder, more calculative and interest-based language - and thus mode of valuation presented earlier is clear. The writer here states her personal, deep and over-generational affinity with the place, and whishes thus that her opinion is given more weight in decision-making. Not because it is as valuable as any other opinion, but because her deep connection makes it more valuable (see also Devine-Wright, 2009).

\section{Conclusions}

In this paper, NIMBY conflicts were seen as political conflicts over local land-use, in which residents (as citizens) act to influence the land-use decisions, through having disputes over the systems of valuation used in the decision-making. In future research, the concept of NIMBY should be used to denote the conflicts, not actors participating in the conflicts. The argumentation of the residents was analysed using a framework with three possible modes of valuation, based on Individual Interests, Public Justification, or Familiar Attachments. 
This kind of meta-moralistic macro level perspective is needed to understand NIMBY and related phenomena in an analytical way - to see what is common between different cases, and what is shared between political cultures. These cross-cultural comparative projects would provide an interesting avenue for future research.

Empirically, in both the cases of Haaga and Rastila, as well as in the citywide sample, a range of different arguments, and different modes of valuations, was found. The conflicts are different, the stakes in them are different, and the argumentation and modes of valuation used are different. And yet, the arguments and modes of valuation are based on a limited number of cultural tools - and are thus available for research.

When contrasting the results with Bell et al (2013), it would seem that there are, after all, quite lot of people arguing in ways traditionally identified with NIMBY: those who oppose land-use based mostly on their private interests. As noted in Thévenot \& Lamont (2000), and Moody \& Thévenot (2000), the specific legitimacy might vary greatly between political cultures. Interestingly, there was great variation in the definitions of common good used in the argumentation within the mode of valuation based on public justification. Whereas in Haaga, the local environment was mostly constructed as through heritage and tradition, in Rastila it was done using green values, the flora and the fauna of the place. And as was expected, the grammar of familiar affinities was present but in a minimal role. This is most probably due to the limitations of the data: more ethnographically focused studies have often found these place attachments in a more prominent role (eg. Blok \& Meilvang, 2014; Richard-Ferroudji, 2011) than is possible with a macro-level study focused on written dispute letters like this.

The written dispute letter data used in this article emphasizes the democratic nature of the NIMBY conflict. Even if the arguments are based on individual interests, they were expressed through the participatory channels available to residents - and the legitimacy of this kind of position can be 
thought to vary between political cultures. In the case of Helsinki, Finland, the residents clearly saw it as a legitimate way of doing local politics: they assumed that simply stating of a preference would be enough to convince the planners.

The framework can also be used for analysing conflicts using more ethnographic or statistical data. Gladarev and Lonkila (2013) compare similar NIMBY conflicts in Russia and Finland, and find the main difference in the primary mode of valuation - in Finland, the activists use public justification, in Russia the emphasis is on the familiar affinities and connections between residents and the nature. Similarly, the Greek protesters presented by Botetzagias and Karamichas (2009) can be said to use the public good of efficiency as the basis for valuation, and the $19^{\text {th }}$ century British villagers offer a mixture of private individual interests (property values) and common goods (the mental patients would cause danger for the residents), when seen through the framework presented here (Bucknill, 1858; Philo, 1987).

The definition of 'private interest' had to be amended, to include not just the lone individual, but also the small-scale community around her. This was possible, because despite the collective nature of these claims, they referenced the private interests of this small group, not general level common goods. In the future research using framework derived from pragmatic sociology, these issues of representation need more attention.

Because of the rather low-intensity-level of these conflicts, they allow us to transcend the idea of NIMBY as something that happens only in highly contested siting or urban planning projects. And, the (in theory) open and democratic nature of the planning process in Helsinki helps to highlight that adding participatory elements to land-use is most certainly not a silver bullet, which would help planners forgo NIMBY style opposition, as many writers have alluded (Wexler, 1996; RichardFerroudji, 2011; Hager and Haddad 2015). This is what NIMBY conflicts look like, when the argumentation is analyzed from the perspective of the residents using the argumentation, and when 
the conflict is understood to be about systems of valuation. Each conflict is unique, but actors use shared cultural tools to participate in the conflicts. And the conflicts are about how decision should be made within the democratic system.

Through this three-category theoretical distinction, it should be possible to better understand NIMBY conflicts, whether they are based on place attachment, private interest or general principles, as conflicts of justice.

\footnotetext{
${ }^{\mathrm{i}}$ This critique has a somewhat problematic relation to critical theory. Boltanski (2011) has seen this mode of situated everyday critique as supplanting the need for critical theory - but Diken (2015) criticises this view of critique, blaming it for losing the radical potential for broad social reconfiguration that is at the heart of critical theory.

ii The dispute letters sent to the city planning authority are available to the public in the foyer of the City Hall by request, so even though they are not confidential, they are not exactly public either.

iii The subset includes a single comment letter from each individual commenter who included an address in the comment letter.
} 


\section{References}

Bell, D., Gray, T., \& Haggett, C. (2005). The "Social Gap" in Wind Farm Siting Decisions: Explanations and Policy Responses. Environmental Politics, 14(4), 460-477.

Bell, D., Gray, T., Haggett, C., \& Swaffield, J. (2013). Re-visiting the “ social gap ”: public opinion and relations of power in the local politics of wind energy. Environmental Politics, 22(1), 115-135.

Block A and Meilvang ML (2014) Picturing urban green attachments: civic activists moving between familiar and public engagements in the city. Sociology 49(1): 19-37.

Boltanski L and Thévenot L (1999) The Sociology of Critical Capacity. European Journal of Social Theory 2(3): 359-377.

Boltanski L and Thévenot L (2006) On Justification. Economies of Worth. Princeton and Oxford: Princeton University Press.

Boltanski L (2011) On Critique. A Sociology of Emancipation. Cambridge: Polity Press.

Botetzagias I and Karamichas J (2009) Grassroots mobilisations against waste disposal sites in Greece. Environmental Politics 18(6): 939-959.

Bucknill JC (1858) Description of the New House at the Devon County Lunatic Asylum, with remarks upon the Sea Side Residence for the Insane, which was for a time established at Exmouth. The British Journal of Psychiatry 4(25): 317-328.

Bullard RD (1990) Dumping in Dixie: Race, class, and environmental quality. Boulder: Westview Press.

Burningham K (2000) Using the language of NIMBY: a topic for research, not an activity for researchers. Local Environment 5(1): 55-67.

Burningham, K., Barnett, J., \& Thrush, D. (2006). The limitations of the NIMBY concept for understanding public engagement with renewable energy technologies: a literature review. Published by the School of Environment and Development, University of Manchester. Available at http://www.sed.manchester.ac.uk/research/beyond_nimbyism/

Bäcklund, Pia (2007) Tietämisen politiikka. Kokemuksellinen tieto kunnan hallinnassa. Helsinki: Helsingin kaupungin tietokeskus.

Backlund, Pia, and Raine Mantysalo (2010) Agonism and Institutional Ambiguity: Ideas on Democracy and the Role of Participation in the Development of Planning Theory and Practice - the Case of Finland. Planning Theory 9(4):333-50.

City of Helsinki (2015) Planning Process and Participation. Available at:http://www.hel.fi/www/Helsinki/en/housing/planning/process/. Accessed 17.5.2016 
Centemeri L (2014) Reframing Problems incommensurability in environmental conflicts through pragmatic sociology. From value pluralism to the plurality of modes of engagement with the environment. Environmental Values 24(3).

Dear MJ and Taylor SM (1982) Not on our street. London: Pion ltd.

Dear, M. (1992). Understanding and overcoming the NIMBY syndrome. Journal of the American Planning Association, 58(3), 288-300.

Devine-wright P (2009) Rethinking NIMBYism: The Role of Place Attachment and Place Identity in Explaining Place-protective Action. Journal of Community \& Applied Social Psychology, 19, 426-441.

Diken, B (2015) Critique as Justification - and beyond. Sociological Review 63:922-39.

Engelhaupt E (2008) Happy Birthday, Love Canal. Environmental Science and Technology 86(46): 46-53.

Feldman S and Turner D (2010) Why Not NIMBY? Ethics, Place and Environment. 13(3), 251266.

Finnish Land-Use and Bulding Act (1999) Available at https://www.finlex.fi/fi/laki/kaannokset/1999/en19990132.pdf

Finnish Ministry of the Environment (2014) Arviointi maankäyttö- ja rakennuslain toimivuudesta 2013. Suomen Ympäristö 1/ 2014. Helsinki: Ympäristöministeriö.

Freudenberg W and Pastor S (1992) NIMBYs and LULUs, stalking the syndromes. Journal of Social Issues 48(4), 39-61.

Gibson TA (2005) NIMBY and the Civic Good. City and Community 4(4), 381-401.

Gladarev B and Lonkila M (2013) Justifying civic activism in Russia and Finland. Journal of Civil Society 9(4): 375-390.

Hager C and Haddad MA (eds) (2015) Nimby Is Beautiful: Cases of Local Activism and Environmental Innovation Around the World. New York, Oxford: Berghahn Books.

Haila, Anne (2002) Suunnittelu ja kaupunkirakentaminen. In Bäcklund Häkli \& Schulman (eds Osalliset ja osaajat - Kansalaiset kaupungin suunnittelussa. Helsinki: Gaudeamus, 92-110.

Hamilton JT (1995) Testing for environmental racism: prejudice, profits, political power? Journal of Policy Analysis and Management 14(1): 107-132.

Hubbard, P. (2006). NIMBY by another name? A reply to Wolsink. Transactions of the Institute of British Geographers. 31(1), 92-94. 
Hogenstijn, M, Van Middelkoop, D and Terlouw, K (2008) The Established, the Outsiders and Scale Strategies: Studying Local Power Conflicts. Sociological Review 56(1):144-61.

Inhaber H (1992) Of LULUs, NIMBYs and NIMTOOs. Public interest 107:52-64.

Kempton, W., Firestone, J., Lilley, J., Rouleau, T., \& Whitaker, P. (2005). The Offshore Wind Power Debate: Views from Cape Cod. Coastal Management, 33, 119-149.

Lafaye C and Thévenot L (1993) Une justification écologique?: Conflits dans l'aménagement de la nature. Revue française de sociologie, 34(4): 495-524.

Lamont M and Thévenot L (2000) Introduction. In Lamont \& Thévenot (eds). Rethinking comparative cultural sociology: Repertoires of evaluation in France and the United States. Cambridge: Cambridge University Press.

Lamont M (2012) Toward a Comparative Sociology of Valuation and Evaluation. Annual Review of Sociology 38(21): 201-221.

Lolive, J (1997) La montée en généralité pour sortir du Nimby. La mobilisation associative contre le TGV Méditerranée. Politix, 10(39), 109-130.

Luhtakallio E (2012) Practicing Democracy. Local Activism and Politics in France and Finland. Basingstoke: Palgrave Macmillan.

Lidskog, R., \& Elander, I. (1992). Reinterpreting locational conflicts: NIMBY and nuclear waste management in Sweden. Policy \& Politics, 20(4), 249-264.

Mannarini T and Roccato M (2011) Uses of the term NIMBY in the Italian press, 1992-2008. Environmental Politics, 20(6), 37-41.

Moody M and Thévenot L (2000) Comparing models of strategy, interests, and the public good in French and American disputes. In Lamont M and Thévenot L (eds) Rethinking comparative cultural sociology: Repertoires of evaluation in France and the United States. Cambridge: Cambridge University Press.

Neveu, Catherine (2002) Nimbys as citizens: (re)defining the general interest. Focaal - European Journal of Anthropology, 40, 51-66.

OurCIty (2012) - An Alternative Plan for Meri-Rastila. Available at https://meidankaupunki.wordpress.com/alternative-master-plan/ Accessed 20.10.2015

Philo C (1987) "Not at our seaside": community opposition to a nineteenth century branch asylum. Area, 19(4), 297-302.

Richard-Ferroudji, A (2011) Limites du modèle délibératif : composer avec différents formats de participation. Politix 24(96): 161-181. 
Roccato M, Rovere A and Bo G (2008) Interessi generali e interessi particolari. In Fedi A, Mannari T (eds) Oltre il NIMBY: La dimensione psicologico-sociale della protesta contro le opere sgradite . Milan: Angeli, 43-66

Rosanvallon P (2008) Counter-democracy: Politics in the Age Distrust. Cambridge: Cambridge University Press.

Saad-Sulonen Joanna (2014) Combining participations:. Expanding the Locus of Participatory EPlanning by Combining Participatory Approaches in the Design of Digital Technology and in Urban Planning. Helsinki: Aalto ARTS books.

Sherman DJ (2015) Hell No, We Won't Glow! How targeted Communities Deployed an Injustice Frame to Shed the NIMBY Label and Defeat Low-level Radioctive Waste Facilities in United States. Hager and Haddad (EDS) Nimby is beautiful. New York, Oxford: Berghahn Books.

Shumaway JM and Jackson RH (2008) Place Making, Hazardous Waste, and the Development of County, Utah. Geographical Review 98(4): 433-455.

Szasz, Andrew (1994): Ecopopulism. Toxic Waste and the Movement for Environmental Justice. Minnesota: University of Minnesota Press.

Staffans, Aija (2012) MRL ja kansalaisten osallistuminen. Ympäristöministeriön raportteja 4/2012. Helsinki: Ympäristöministeriö.

Swidler, Ann (1986) Culture in Action: Symbols and Strategies. American Sociological Review 51(2): 273.

Thévenot L (2007) The plurality of cognitive formats and engagements. Moving between the familiar and the public. European Journal of Social Theory 10(3): 413- 427.

Thévenot L (2014) Voicing concern and difference: from public spaces to common-places. European Journal of Political and Cultural Sociology, 1(1), 7-34.

Thévenot L (2015) Making commonality in the Plural on the Basis of binding engagements. In Dumouchel P and Gotoh R (eds) Social Bonds as Freedom. Revisiting the Dichotomy of the Universal and the Particular New York, Oxford: Berghahn books.

Thévenot L, Moody M and Lafaye C (2000) Forms of Valuing Nature: Arguments and Models of Justification in French and American Environmental Disputes. In Lamont M and Thévenot L (eds) Rethinking comparative cultural sociology: Repertoires of evaluation in France and the United States. Cambridge: Cambridge University Press.

Thévenot L and Lamont M (2000) Conclusion: Exploring the French and American Polity. In Lamont M and Thévenot L (eds) Rethinking comparative cultural sociology: Repertoires of evaluation in France and the United States. Cambridge: Cambridge University Press. 
Trom D.(1999). De la refutation de l'effet "NIMBY" considérée comme une pratique militante: Notes pour une approche pragmatique de l'activité revendicative. Revue française de science politique, 49(1), 31-50.

Wexler MN (1996) A Sociological Framing of the NIMBY (Not-In-My-Backyard) Syndrome. International Review of Modern Sociology 26(1): 91-110.

Wolsink M (2006) Invalid theory impedes our understanding: a critique on the persistence of the language of NIMBY. Transactions of the Institute of British Geographers 31(1): 85-91.

Ylä-Anttila Tuomas and Luhtakallio E (2016) Justifications analysis: Understanding moral evaluations in public debates. Forthcoming in Sociological Research Online.

Ylä-Anttila Tuukka (2016) Populism and Familiarity: Political Appropriation of Suvivirsi, the Summer Hymn. Forthcoming 